\title{
The Impact of Valve Calcifications Upon the Haemodynamic Severity of Aortic Stenosis
}

\author{
CRISTINA FURNICA ${ }^{1,2}$, LACRAMIOARA PERIANU ${ }^{1,3 *}$, ANDRA OANCEA (RADULESCU) ${ }^{1,4 *}$, \\ CARMINA MIHAELA SCHAAS ${ }^{1,5 *}$, GRIGORE TINICA ${ }^{1,6}$ \\ ${ }^{1}$ Grigore T. Popa University of Medicine and Pharmacy, 16 Universitatii Str., 700115, Iasi, Romania \\ ${ }^{2}$ Institute of Forensic Medicine, 4 Buna Vestire Str., 700455, Iasi, Romania \\ ${ }^{3}$ Sf. Spiridon Emergency Clinical Hospital, 1 Independentei Blvd., 700111, Iasi, Romania \\ ${ }^{4}$ Clinical Rehabilitation Hospital, 14 Pantelimon Halipa str., 700661, Iasi, Romania \\ ${ }^{5}$ Cuza Voda Clinical Obstetrics and Gynecology Hospital, 34 Cuza Voda Str., 700038, Iasi, Romania \\ ${ }^{6}$ Institute for Cardiovascular Diseases, 50 Carol I Blvd., 700503, Iasi, Romania
}

The calcific aortic stenosis (AS) is characterized by progressive obstruction of the aortic valve opening and results from the action of several active cellular processes that lead to valve remodelling, promote fibrosis and valvular calcification. The purpose of the study is to assess the relationship between the severity of aortic valve calcifications quantified by the Agatston score density and the hemodynamic impact of aortic stenosis determined through Doppler echocardiography. The authors performed a retrospective analysis of 70 cases that benefited of transcatheter aortic valve implantation between January 2015-October 2019. All patients underwent cardiac computed tomography and comprehensive Doppler echocardiography prior to the procedure. The degree of calcification of aortic leaflets was quantified on non-contrast CT examinations in all cases using the Agatston score and its relationship with dynamic echocardiographic parameters was evaluated using specific statistical tests. Aortic valve Agatston score density showed a significant correlation with mean transvalvular gradient $(R=0,62$, $p<0.0001)$ same as age $(R=0.51, p=0.036)$. These parameters together with sex, body mass index, body surface area, the status of arterial hypertension, dyslipidaemia, smoking, bicuspid aortic valve, history of coronary artery disease were introduced into a multivariate regression to identify independent predictors of the mean transvalvular gradient. Age $(\beta=-0.25, p=0.003)$, aortic valve Agatston score density $(\beta=-0.63, p<0.001)$ and bicuspid aortic valve $(\beta=-0.32, p=$ $0,003)$ proved to be the only independent predictors of the haemodynamic severity of aortic stenosis. In conclusion, the degree of aortic valve calcifications is a strong indicator for the haemodynamic impact of AS. Cardiac computed tomography is a non-invasive and accurate method of evaluating aortic valve calcifications and could be used to grade the severity of AS in cases where echocardiographic findings are discordant.

Keywords: transcatheter aortic valve implantation, leaflet calcification, hydroxyapatite, Agatston score, transvalvular gradient

The calcific aortic stenosis (AS) is characterized by progressive obstruction of the aortic valve opening and results from the action of several active cellular processes that lead to valve remodelling, promote fibrosis and valvular calcification. The first stage of the disease is called aortic valve sclerosis, mainly characterized by thickening of valvular leaflets, and is not associated with significant obstruction of the valve opening. Aortic sclerosis marks the beginning of a continuum leading to AS and its progression over time. Although it does not yet alter the hemodynamic properties of the valve, some studies show that aortic valve sclerosis is associated with atherosclerosis and a higher risk of cardiovascular events [1-3]. Its prevalence is around 25\% among people over 65 years of age, and every year about $2 \%$ of these individuals will progress to AS [4-6]. Aortic stenosis has long been considered to be the result of passive degeneration of the valve with aging, but it is well demonstrated today that many active processes are involved in its initiation and progression [7].

Aortic valve stenosis begins with damage to the valvular endothelium triggered by mechanical stress, radiation, accumulation of oxidized low-density lipoprotein (LDL) and inflammation (cytokines) that will promote a cascade of pro-inflammatory processes and calcification through overexpression of osteogenic genes. Following years of aggression, aortic leaflets' fibrosis and deposition of hydroxyapatite $\left(\mathrm{Ca}_{10}\left(\mathrm{PO}_{4}\right)_{6}(\mathrm{OH})_{2}\right)$ crystals obstruction of the valve opening occurs with severe hemodynamic consequences $[8,9]$.

*email: lacrima12@gmail.com; andra.radulescu@yahoo.com; michy_doctor@yahoo.com 
The purpose of the current study is to assess the relationship between the severity of aortic valve calcifications quantified by the Agatston score density and the hemodynamic impact of aortic stenosis determined through Doppler echocardiography.

\section{Experimental part}

Material and methods

We performed a retrospective analysis of 70 cases who benefited of transcatheter aortic valve implantation (TAVI) between January 2015-October 2019. Relevant clinical data was registered in all cases (age, sex, height, body surface area, body mass index, personal history of arterial hypertension, diabetes, dyslipidaemia, coronary heart disease and smoking). All patients underwent cardiac computed tomography and comprehensive Doppler echocardiography prior to the procedure.

All echocardiographic evaluations were performed on a General Electric Vivid E9 machine according to the recommendations of the European Society of Cardiology and involved determining the following parameters: stroke volume index, left ventricular outflow tract (LVOT) diameter, LVOT cross-sectional area, peak aortic jet velocity, aortic valve area (AVA), left ventricular ejection fraction (LVEF), transvalvular mean gradient (MG), valvulo-arterial impedance, systemic arterial compliance.

Cardiac computed tomography (CCTA) examinations were performed on a $2 \times 128$-slices multi-detector CT (MDCT) machine (Siemens Somatom Definition Flash) using 100 or $120 \mathrm{kV}$ tube voltage according to patient weight, tube current automatically adjusted by CareDose 4D algorithm, $0.75 \mathrm{~mm}$ slice thickness (pitch <1) and a gantry rotation time of $280 \mathrm{~ms}$. The examination started with an unenhanced scan for calcium scoring evaluation followed by a contrast enhanced scan. An average volume of $120 \mathrm{~mL}$ of contrast media and $50 \mathrm{~mL}$ of saline chaser were injected intravenously in two phases, an initial fast injection of $100 \mathrm{~mL}$ of iodinated contrast media $(5 \mathrm{~mL} / \mathrm{s})$ followed by a slower injection of $20 \mathrm{~mL}$ contrast media $(2.5 \mathrm{~mL} / \mathrm{s})$ and $50 \mathrm{~mL}$ saline chaser $(5 \mathrm{~mL} / \mathrm{s})$. The heart was scanned using ECG gating during a first breath hold and the abdominal aorta and iliac vessels during a second breath hold with no ECG synchronisation.

Optimal systolic reconstructions of the cardiac acquisition were performed and transfered to the Syngo.via workstation (Siemens Medical Solutions, Germany) for specific analysis. The following parameters were determined on the cardiac computed tomography: systolic area of the aortic annulus, LVOT area, AVA, height of the coronary arteries, aortic root diameters, aortic valve calcification (AVC) score (Agatston method), AVC density (AVC value indexed to LVOT area).

Agatston score is a partially automated tool implemented in Syngo.via that computes a calcium score based on unenhanced cardiac CT. We assessed only the calcifications of the aortic leaflets paying attention to exclude aortic wall, mitral annulus and coronary calcifications. The computation uses a weighted score attributed to the highest attenuation value in Hounsfield units multiplied by calcification area:

Agatston score $=$ Area $\times \mathrm{X}$-Factor,

the X-Factor can take a value between 1 and 4 according to the value range of the highest intensity pixel of the plaque $(130-199=$ value $1,200-299=$ value $2,300-399=$ value $3, \geq 400=$ value 4$)$.

Statistical analysis was performed in IBM SPSS 25.0 for Mac. Continuous variables were expressed as mean values \pm standard deviation and compared using Student's $t$ test or Wilcoxon-Mann-Whitney depending on the normal distribution. Categorical variables were expressed as ranks or percentages and analysed using chi-square or Fisher's exact test. Association between continuous variables was tested using Pearson correlation.

\section{Results and discussions}

The clinical data of the studied population is presented in table 1. Patients with bicuspid aortic valves represented $20 \%$ of the study group.

Table 1

CLINICAL DATA OF THE STUDIED POPULATION

\begin{tabular}{|c|c|}
\hline Age (years) & $76.47 \pm 6.83$ \\
\hline Sex (no. \% female) & $37(52.86 \%)$ \\
\hline BMI (kg/m $\mathbf{m}^{\mathbf{2}}$ & $28.56 \pm 4.05$ \\
\hline EuroSCORE II & $22.42 \pm 14.12$ \\
\hline AHT (no. \%) & $32(45.71 \%)$ \\
\hline NYHA (no. \%) & NYHA II - 2 (2.86\%) \\
& NYHA III - 43 (61.43\%) \\
& NYHA IV - 25 (35.71\%) \\
\hline Type 2 DM (no. \%) & $8(11.43 \%)$ \\
\hline AMI (no. \%) & $8(11.43 \%)$ \\
\hline Stroke & $5(7.14 \%)$ \\
\hline
\end{tabular}


(a) and determines Lp (a) levels is associated with the development and progression of calcific AS, in addition to being a risk factor for cardiovascular diseases $[17,18]$. High Lp (a) levels are associated with a higher prevalence of AS.

Inflammation plays a major role in the initiation and development of AS. Indeed, it promotes sclerosis, remodelling and calcification of the valve [19]. It can initiate the disease by the action of pro-inflammatory cytokines that can damage the valvular endothelium, but it can also intervene in response to endothelial damage by recruiting immune cells. Explanted valve analysis shows infiltrates containing macrophages, mast cells and T cells [20]. Finally, it can maintain the already present inflammation, caused by the infiltration and oxidation of lipids (102). Many proinflammatory cytokines are also secreted by inflammatory cells and will end up in the valve. They will promote calcification by activating and stimulating interstitial cells differentiation into osteoblasts. Proinflammatory and profibrotic cytokines increase extracellular matrix production and cell turnover, resulting in stiffening and fibrosis of the valve matrix.

In the development and progression of AS, the imbalance between overproduction of matrix metalloproteinases (MMPs) and tissue inhibitors of metalloproteinases (TIMPs) that are underproduced, causes disruption of the collagen fibres. This disorganized fibrous tissue accumulated in the valve will increase its stiffness. In addition, angiotensin II, often present in high plasmatic concentrations in patients with calcific AS, is associated with inflammation and remodelling of the valve [21]. Angiotensin II is thus overproduced and promotes fibrosis and valvular remodelling. Animal studies in mice have shown that the administration of angiotensin II promotes fibrosis in the aortic valve [22]. In contrast, administration of angiotensin II receptor antagonists is associated with less fibrocalcic remodelling of valve leaflets.

Valve calcification is the most common factor associated with AS and disease progression. The first lesions of the valve appear preferentially and remain predominant on the aortic side of the leaflets. This valve layer is more prone to mechanical shear stress and high pressures of the aorta following closure of the valve. The valvular calcification process has many similarities with bone development. In particular, there are numerous osteogenic genes overexpressed in human stenotic valves, including BMP2 and RUNX2 [23]. The interstitial cells of the valve would be "reprogrammed" into osteoblast-like cells able to secrete pro-calcifying vesicles. In human valves, osteogenic and apoptotic processes contribute to valve calcification [24].

In our study, the density of aortic valve calcifications quantified through Agatston score, proved an independent predictor of transvalvular mean gradient. Non contrast coronary CT could be used both for coronary artery disease risk estimation and AS assessment and we plead for its introduction into standard evaluation of patients with calcific AS prior to any surgical or interventional treatment.

\section{Conclusions}

The degree of aortic valve calcifications is a strong indicator for the haemodynamic impact of AS. Cardiac computed tomography is a non-invasive and accurate method of evaluating aortic valve calcifications and could be used to grade the severity of AS in cases where echocardiographic findings are discordant.

\section{References}

1.ROSSI, A., FAGGIANO, P., AMADO, A.E., CICOIRA, M., BONAPACE, S., FRANCESCHINI, L., Int. J. Cardiol., 158, no. 1, 2012 , p. 163. 2.PRASAD, Y., BHALODKAR, N.C., Clin. Cardiol., 27, no. 12, 2004, p. 671.

3.SAPLACAN, R.M.M., CATINEAN, A., MANOLE, S., VALEAN, S.D., CHIRA, R.I., MIRCEA, P.A., Medical Ultrasonography, 13, no. 2, 2011, p. 165.

4.STEWART, B.F., SISCOVICK, D., LIND, B.K., GARDIN, J.M., GOTTDIENER, J.S., SMITH, V.E., J. Am. Coll. Cardiol., 29, no. 3, 1997, p. 630 .

5.COSMI, J.E., KORT, S., TUNICK, P.A., ROSENZWEIG, B.P., FREEDBERG, R.S., KATZ, E.S., Arch. Intern. Med., 162, no. 20, 2002, p. 2345.

6.COFFEY, S., COX, B., WILLIAMS, M.J., J. Am. Coll. Cardiol., 63, no.25, 2014, p. 2852

7.MILLER, J.D., WEISS, R.M., HEISTAD, D.D., Circ. Res., 108, no. 11, 2011, p. 1392.

8.MARTHA, K., OGODESCU, A., ZETU, I., OGODESCU, E., PACURAR, M., Rev. Chim. (Bucharest), 64, no. 9, 2013 , p. 982.

9.FURNICA, C., CHISTOL, R.O., LEON CONSTANTIN, M.M., ALEXA, A.I., TINICA, G., Rev.Chim. (Bucharest), 66, no. 10,2015 , p. 1716. 10.LEOPOLD, J.A., Circ. Cardiovasc. Interv., 5, no. 4, 2012, p. 605.

11.CHEN, J.H., SIMMONS, C.A., Circ. Res., 108, no. 12, 2011, p. 1510.

12.O'BRIEN, K.D., REICHENBACH, D.D., MARCOVINA, S.M., KUUSISTO, J., ALPERS, C.E., OTTO, C.M., Arterioscler. Thromb. Vasc.

Biol., 16, no. 4, 1996, p. 523.

13.MOHTY, D., PIBAROT, P., DESPRÉS, J.P., CÔTÉ, C., ARSENAULT, B., CARTIER, A., Arterioscler. Thromb. Vasc. Biol., 28, no. 1, 2008, p. 187.

14.CÔTÉ, C., PIBAROT, P., DESPRÉS, J.P., MOHTY, D., CARTIER, A., ARSENAULT, B.J., Heart., 94, no. 9, 2008 , p. 1175.

15.CAPOULADE, R., CHAN, K.L., YEANG, C., MATHIEU, P., BOSSÉ, Y., DUMESNIL, J.G., J. Am. Coll. Cardiol., 66, no. 11, 2015, p. 1236.

16.GILCA, G.E., DIACONESCU, S., BALAN, G.G., TIMOFTE, O., STEFANESCU, G., Medicine, 96, no. 10, 2017, Article Number: e6156, DOI: 10.1097/MD.0000000000006156

17.THANASSOULIS, G., CAMPBELL, C.Y., OWENS, D.S., SMITH, J.G., SMITH, A.V., PELOSO, G.M., N. Engl. J. Med., 68, no. 6, 2013, p. 503. 
18.KAMSTRUP, P.R., TYBJAERG-HANSEN, A., NORDESTGAARD, B.G., J. Am. Coll. Cardiol., 63, no. 5, 2014 , p. 470.

19.ABDELBAKY, A., CORSINI, E., FIGUEROA, A.L., SUBRAMANIAN, S., FONTANEZ, S., EMAMI, H., Atherosclerosis, 238, no. 2, 2015, p. 165.

20.CÔTÉ, N., MAHMUT, A., BOSSÉ, Y., COUTURE, C., PAGÉ, S., TRAHAN, S., Inflammation, 36, no. 3, 2013, p. 573.

21.CÔTÉ, N., PIBAROT, P., PÉPIN, A., FOURNIER, D., AUDET, A., ARSENAULT, B., Int. J. Cardiol., 145, no. 3, 2010 p. 444.

22.FUJISAKA, T., HOSHIGA, M., HOTCHI, J., TAKEDA, Y., JIN, D., TAKAI, S., Atherosclerosis, 226, no.1, 2013 , p. 82.

GUAUQUE-OLARTE, S., MESSIKA-ZEITOUN, D., DROIT, A., LAMONTAGNE, M., TREMBLAY-MARCHAND, J., LAVOIECHARLAND, E., Circ. Cardiovasc. Genet., 8, no. 6, 2015, p. 812.

23.HUNEA, I., DAMIAN, S.I., RADU, C.C., MOLDOVEANU, S., IOV, T., Rev.Chim. (Bucharest), 69, no. 9, 2018 , p. 2482.

Manuscript received: 11.12 .2019 